Halichidis Stela

\title{
Tigecycline For Skin Infection With SIRS In Immunocompromised Host
}

"Ovidius" University of Constanta, Faculty of Medicine, Discipline Infectious Diseases

\begin{abstract}
:
Tigecycline is the first agent in the new class of glycylcycline antibiotics.

It's expanded broad spectrum of activity, with demonstrated efficacy as monotherapy against clinically important Gram-positive and Gram-negative pathogens include also anerobes and antibiotic-resistant isolates.

It is presented the case of a 54 years old man, recently diagnosed with HIV infection, that had high fever and skin abscesses. The laboratory investigations showed a Systemic Inflammatory Response Syndrome.

After 10 days of treatment with Tygacil, $100 \mathrm{mg}$ at first, then $50 \mathrm{mg} / 12$ hours, surgical incision and drainage, antiinflammatory and symptomatic treatment, the patient's symptoms disappeared and we started also the antiretroviral therapy.
\end{abstract}

Key words: tigecycline, skin, systemic inflammatory response

\section{Introduction}

Tigecycline, the first agent in the new class of glycylcycline antibiotics, has an expanded broad spectrum of activity, with demonstrated efficacy as monotherapy against clinically important Grampositive and Gram-negative pathogens and anerobes, including antibiotic-resistant isolates $[1,2,3,4]$.

The drug is efficacious in patients with secondary peritonitis, abcesses, complicated skin and soft tissue infection and is well tolerated without any adverse events [5].

It is presented the case of a patient, recently diagnosed with HIV infection, that had high fever and skin abscesses, treated with Tigecycline.

\section{Materials and methods}

A 54-years old, male patient, recently diagnosed with AIDS, was admitted in our clinic because of fever during the last 10 days.

On clinical examination we found two old abscesses, one in perianal region, and the other on the anterior half part of the left calf (Figure 1)

\footnotetext{
University „Ovidius” Constanta

Faculty of Medicine

Department of Infectious Diseases

E-mail: shalichidis@yahoo.com

Bul. Ferdinand 100 - Constanta

Tel +40241484500
} 


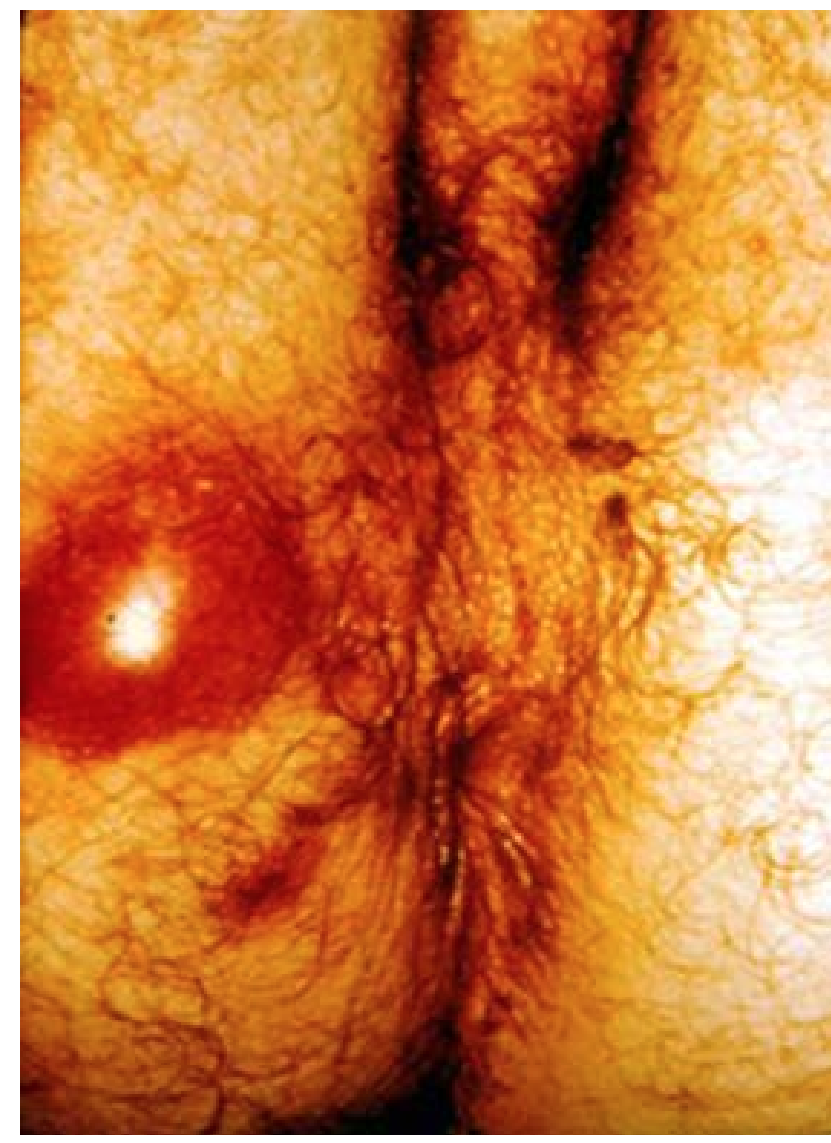

Figure 1 - clinical aspect of the abcess

Laboratory findings:

- HIV tests (two ELISA and one Westernblot) positive

- White blood cells $14000 / \mathrm{uL}$, granulocites $80 \%$

- $\quad$ CD4 128

- CD8 1253

- CD3 1373

- $\mathrm{CD} 4 / \mathrm{CD} 80,10$

- HIV-RNA $932000 \mathrm{c} / \mathrm{ml}$

- Erythrocytes 3240000/uL

- $\mathrm{Hb} 10,4 \mathrm{~g} / \mathrm{dL}$

- Thrombocytes $113000 / \mathrm{uL}$

- ESR $60 \mathrm{~mm} / \mathrm{h}$

- Fibrinogen $840 \mathrm{mg} / \mathrm{dL}$

- Ureea $50 \mathrm{mg} / \mathrm{dL}$

- Creatinine $1,2 \mathrm{mg} / \mathrm{dL}$

- ALT $55 \mathrm{U} / \mathrm{L}$
- AST $61 \mathrm{U} / \mathrm{L}$

- No pathogen agent isolated from the abscesses

\section{Results}

After 10 days of treatment that consisted of: Tygacil, $100 \mathrm{mg}$ at first, then $50 \mathrm{mg} / 12$ hours, surgical incision and drainage, antiinflammatory and symptomatic treatment, the patient's symptoms disappeared and we started also the antiretroviral therapy.

\section{Conclusions}

The evolution of this case and the conclusions of many clinical trials and studies shows us that Tygecycline demonstrated efficacy as monotherapy against severe infections, even in immunocompromised patients and antibioticresistant strains.

\section{References}

1. E. David McIntosh. (2009) - Glycylcyclines: Current Research Directions - STEP Progress in Infection (section 5). Athens, Greece: Wyeth

2. Ellis-Grosse EJ, Babinchak T, Dartois N, Rose G, Loh E.( 2005). for the Tigecycline 300 and 305 cSSSI Study Groups - The efficacy and safety of tigecycline in the treatment of skin and skinstructure infections: results of 2 double-blind phase 3 comparison studies with vancomycin- 
aztreonam - Clinical Infectious Diseases; 41 Suppl 5 (S341-S353). Oxford University Press.

3. Zhanel GG, Karlowsky JA, Rubinstein E, Hoban DJ. (2006). - Tigecycline: a novel glycylcycline antibiotic - Expert Rev Anti Infective Therapy 4: (pp.9-25). London: Expert Reviews Ltd.

4. Babinchak T, Ellis-Grosse E, Dartois N, Rose GM, Loh E. (2005). for the Tigecycline 301 and 306 Study Groups - The efficacy and safety of tigecycline for the treatment of complicated intraabdominal infections: analysis of pooled clinical trial data.Clinical Infectious Diseases; 41 suppl 5
(S354-S367). ). Oxford University Press.

5. Rita Piscopo, Giovanni Penco, Marcello Feasi, Emanuele Pontali, Nicoletta Bobbio, Giovanni Cassola. (2009). STEP Progress in Infection( section 8). Athens, Greece: Wyeth. 